\title{
Quantification of Iron, Magnesium and Phosphorus contents of selected local dishes in Minna, Nigeria
}

\author{
Salau, Rasaq Bolakale ${ }^{1}$, AbdulKarim Ali Deba ${ }^{2}$ and Jimoh Yusuf ${ }^{3}$ \\ ${ }^{\text {I}(C h e m o m e t r i c s ~ R e s e a r c h, ~ D e p t . ~ o f ~ C h e m i s t r y, ~ F a c . ~ o f ~ S c i ., ~ U n i v e r s i t i ~ T e k n o l o g i ~ M a l a y s i a, 81310, S k u d a i, ~}$ \\ Johor) \\ ${ }^{1,3}$ (Department of Chemistry, Federal University of Technology, P.M.B 65, Minna, Nigeria) \\ ${ }_{2}^{2}$ (Science Education Programme, Abubakar Tafawa Balewa University, Bauchi, Nigeria)
}

\begin{abstract}
Selection of eleven (11) different local dishes frequently consumed in Minna, North central part of Nigeria, was based on the food consumption survey carried out in form of questionnaire. The quantity of magnesium and iron was determined using Flame Atomic Absorption Spectrometer (AAS) while phosphorus was obtained using colorimetric method involving Phospho Vanado Molybdate Complex, after wet ashing method. The result showed iron, magnesium and phosphorus load $(\mathrm{mg} / 100 \mathrm{~g})$ ranged from $4.35 \pm 0.07$ to $10.62 \pm 0.04,131.30 \pm 0.09$ to $322.40 \pm 0.08,131.30 \pm 0.01$ to $165.00 \pm 0.02$, respectively. The three mineral loads observed were capable of meeting the required dietary allowance in WHO and FAO standard. Therefore, careful choice among the studied local food will exhibit inherent natural remedy capability for the malnutrition of Iron, magnesium and Phosphorus mineral.
\end{abstract}

Keywords: Local dishes, Minna, Iron, magnesium, Phosphorus, natural remedy, mineral malnutrition

\section{INTRODUCTION}

Fundamental importance of food to life cannot be over emphasized. It is essential for the development and some functions such as maintenance and reproduction. Dietary study is the investigation of the sum of food consumed by individual or group of persons or organism. Dietary intake has a lot to do with culture, religion, geographical and socioeconomic class [1]. Food is a basic necessity of life. An adequate or proportionate food intake, in terms of quantity and quality, is a pre-requisite for productive and healthy life. Food is also a massive unit of financial budget of households. There is therefore a strong need for a reasonable selection of dietary rich foods from health and economic point of view.

Mineral elements constitute an important class of food. Lack, inadequate or excessive presence of minerals could lead to disease or health disorder. Each essential mineral element plays specific health function. Ignorance or wrong intake of foods [2] is said to have placed about two billion people in the world below their mental and physical capabilities. This affects mostly the residents of the continents of Africa and Asia [3].

Minerals are grouped into major or trace. Major essential minerals are needed in the diet in amounts of 100 milligrams (mg) or more each day while the trace essential minerals are required less or sometimes far less than 100mg. The major minerals include calcium, chloride, magnesium, phosphorus, potassium and sulphur. Trace minerals include iron, iodine, zinc, fluoride, selenium, copper, chromium, manganese, and molybdenum.

Iron, a trace element, has several vital functions in the body. It serves as a carrier element of oxygen from the lung to the tissue by the red blood cell hemoglobin which serves as a transport medium for electrons within the cells. Iron also functions as part of some important enzyme systems in various tissues where it serves as a cofactor for many enzymatic reactions. This element is also found in oxygen storing protein myoglobin where it is stores oxygen for working muscles. Iron deficiency is considered as number one nutritional disorder in the world [4]. About 30\% of the world's population may have iron deficiency anemia while about $80 \%$ may be, generally, iron deficient [5]. Women that are pregnant and those of childbearing age, infants and teenage girls and individual with kidney failure are at greatest risk of developing iron deficiency anemia because they have the greatest need for iron. The Required Daily Allowance (RDA) for Iron [2] ranges from 8mg/day in male adults (19-50 years) to $45 \mathrm{mg}$ /day in adolescents (14-18 years).

Magnesium plays an essential physiological role in many functions of the body [6]. This role is achieved through two important properties of magnesium; the ability to form chelates with important intracellular anionic-ligands, especially ATP, and its ability to compete with calcium for binding sites on proteins and membranes [7]. This synchronization whereby magnesium induces muscle relaxation and calcium aids muscle relaxation brings about movement. Magnesium deficiency may lead to cardiovascular disease and immune dysfunction, which its adequate presence ought to protect [8].The Required Daily Allowance (RDA) for Magnesium [2] ranges from $310 \mathrm{mg} /$ day in female adults (19-30 years) to $420 \mathrm{mg} /$ day in Male adults (31 years and above). 
Quantification of Iron, Magnesium and Phosphorus contents of selected local dishes in Minna,

Phosphorus with calcium, phosphate is the main component of the inorganic part of the skeleton. Organophosphorus compounds are the building blocks of nucleic acids in all living cells. Phospholipids, like lecithins, are elements of cell membranes. Phosphorylation reactions regulate many metabolic processes of the cell. The consumption of a diet sufficient in phosphorus, in the form of phosphate salts or organophosphate molecules, is critical for the support of human metabolic functions. There is need for delicate balance between phosphorus and calcium in diet to ensure good bone development and prevention of osteoporosis. Persistent hypophosphataemia (Inadequate Phosphorus intake) can lead to health and growth disorders such as rickets in children, skeletal deformations, haemolytic anaemia, cardiomyopathy and osteomalacia (weak bones) in adults [9]. The Required Daily Allowance (RDA) for Phosphorus [10] ranges from $100 \mathrm{mg} / \mathrm{day}$ in infants (0-6 months) to $1,250 \mathrm{mg}$ /day in pregnant and breastfeeding females under 18 years.

This study on widely consumed local dishes is aimed at quantifying iron and magnesium using Flame atomic absorption spectroscopy (FAAS) and Phosphorus by colorimetric method involving Phospho Vanado Molybdate Complex. This is compared with standard required dietary allowance (RDA) so as to expose the local food potentials in remedying some mineral deficiency diseases in the local community.

\subsection{Sample Collection, Treatment and Preparation}

\section{Materials And Methods}

Food consumption survey was conducted using questionnaire and administered on 103 individuals within Minna metropolis of North central part of Nigeria. Information was obtained on eleven (11) frequently consumed traditional foods. The eleven traditional dishes noted include

001. Tuwon shinkafa da miyan wake

003. Amala da miyan ayayo

005. Tuwon Alkama da miyan Kuka

007. Tuwon masara da bushashan kubewa

009. Kunun tsamiya

011. Fura da nono.

The foods served as adult ready to eat adult size of average weight $250 \mathrm{~g}$, were obtained from six different location of Minna city from well patronized traditional food kitchens. Others not obtained from the kitchens were obtained from local markets around.

\subsection{Sample Pretreatment and Ashing}

Large Ceramic Pestle and mortar were previously washed, cleaned and cleansed with concentrated Nitric Acid and then distilled water. These food samples were homogenized thoroughly in the ceramic pestle and mortar accommodating the minutest component of the food mixture. The mixture continued until homogeneous blend which was later transferred to oven, in previously cleaned porcelain crucibles. The samples were fully dried at $110^{\circ} \mathrm{C}$ for 48 hours. Dried sample were grinded into fine powder in titanium blade grinding machine. The fine powder of $100 \mathrm{~g}$ was the average dried sample obtained. This was then kept separately in polyethylene bags, sealed, labeled and kept until further actions.

$1.0 \mathrm{~g}$ of each dried food samples was carefully weighed into $250 \mathrm{~cm}^{3}$ beaker. And $18 \mathrm{ml}$ of nitric acid, $2.0 \mathrm{ml}$ of Perchloric acid and $1.0 \mathrm{ml}$ of Sulphuric acid was added to the sample and heated on a hot plate at about $80^{\circ} \mathrm{C}$. The digestion continued until a clear solution was obtained to signify a complete digestion. After cooling, the digested sample were filtered and diluted to $250 \mathrm{ml}$ with distilled water into a $250 \mathrm{ml}$ volumetric flask which was then transferred into a sample bottle for further analysis.

\subsection{Sample determination}

Flame atomic absorption spectroscopy (FAAS) determined Iron and Magnessium content of the samples while colorimetric method involving Phospho Vanado Molybdate Complex was used to determine phosphorus.

\section{TABLE 1}

Mineral load of the local dishes in $\mathbf{m g} / 100 \mathrm{~g}$ of the dried samples

\begin{tabular}{|c|c|c|c|c|}
\hline SAMPLES & MAIN INGREDIENTS & Iron & Magnesium & Phosphorus \\
\hline 001 & $\begin{array}{l}\text { Wheat, baobab,red palm oil,pepper, } \\
\text { onion, water, locust beans,,maggi } \\
\text { spice,salt and water. }\end{array}$ & $10.60^{\mathrm{a}} \pm 0.04^{\mathrm{c}}$ & $322.40^{\mathrm{a}} \pm 0.08^{\mathrm{c}}$ & $165.00^{\mathrm{a}} \pm 0.05^{\mathrm{c}}$ \\
\hline 002 & Yam,melon,pumpkin- & $7.35^{\mathrm{a}} \pm 0.02^{\mathrm{c}}$ & $151.65^{\mathrm{a}} \pm 0.00^{\mathrm{c}}$ & $105.12^{\mathrm{a}} \pm 0.00^{\mathrm{c}}$ \\
\hline
\end{tabular}

leaves, crayfish,red-

oil,meat,onion,pepper,tomatoes,

maggi,salt,and water. 
Quantification of Iron, Magnesium and Phosphorus contents of selected local dishes in Minna,

\begin{tabular}{|c|c|c|c|c|}
\hline 003 & $\begin{array}{l}\text { Semovita, fresh okra, garlic, } \\
\text { onion,pepper,fish,maggi, salt,fish,red- } \\
\text { oil,meat and water. }\end{array}$ & $5.85^{\mathrm{a}} \pm 0.01^{\mathrm{c}}$ & $205.40^{\mathrm{a}} \pm 0.07^{\mathrm{c}}$ & $120.23^{\mathrm{a}} \pm 0.00^{\mathrm{c}}$ \\
\hline 004 & $\begin{array}{l}\text { Rice,sugar,baking-powder,Yeast, } \\
\text { pepper,tomatoes,salt,maggi,red } \\
\text { oil,groundnut oil,meat, water and } \\
\text { pumkin-leaves. }\end{array}$ & $5.60^{\mathrm{a}} \pm 0.01^{\mathrm{c}}$ & $190.75^{\mathrm{a}} \pm 0.09^{\mathrm{c}}$ & $60.15^{\mathrm{a}} \pm 0.01^{\mathrm{c}}$ \\
\hline 05 & $\begin{array}{l}\text { Rice,beans,redoil,maggi, } \\
\text { salt,pepper,tomatoes, meat, water,and } \\
\text { onion. }\end{array}$ & $10.60^{\mathrm{a}} \pm 0.04^{\mathrm{c}}$ & $132.10^{\mathrm{a}} \pm 0.02^{\mathrm{c}}$ & $90.22^{\mathrm{a}} \pm 0.03^{\mathrm{c}}$ \\
\hline 6 & $\begin{array}{l}\text { Powdered-yam,salt,locust-beans,jute- } \\
\text { vegetable, and water. }\end{array}$ & $8.85^{\mathrm{a}} \pm 0.05^{\mathrm{c}}$ & $233.10^{\mathrm{a}} \pm 0.04^{\mathrm{c}}$ & $90.35^{\mathrm{a}} \pm 0.08^{\mathrm{c}}$ \\
\hline 7 & $\begin{array}{l}\text { Millet,sugar,tamarind,clover,ginger,and } \\
\text { pepper. }\end{array}$ & $8.10^{\mathrm{a}} \pm 0.03^{\mathrm{c}}$ & $131.30^{\mathrm{a}} \pm 0.09^{\mathrm{c}}$ & $30.75^{\mathrm{a}} \pm 0.01^{\mathrm{c}}$ \\
\hline 8 & $\begin{array}{l}\text { Groundnut, corn, bitter lemon, } \\
\text { and sugar. }\end{array}$ & $8.05^{\mathrm{a}} \pm 0.04^{\mathrm{c}}$ & $280.05^{\mathrm{a}} \pm 0.07^{\mathrm{c}}$ & $97.64^{\mathrm{a}} \pm 0.03^{\mathrm{c}}$ \\
\hline 0 & $\begin{array}{l}\text { Maize,water,dried-okra, } \\
\text { meat,onion,pepper,saltand maggi, }\end{array}$ & $10.60^{\mathrm{a}} \pm 0.00^{\mathrm{c}}$ & $255.90^{\mathrm{a}} \pm 0.04^{\mathrm{c}}$ & $105.23^{\mathrm{a}} \pm 0.02^{\mathrm{c}}$ \\
\hline & Beans, pepper, salt and water. & $4.35^{\mathrm{a}} \pm 0.07^{\mathrm{c}}$ & $277.90^{\mathrm{a}} \pm 0.01^{\mathrm{c}}$ & $75.28^{\mathrm{a}} \pm 0.00^{\mathrm{c}}$ \\
\hline & Millet,clover,ginger,pepper and milk. & $8.85^{\mathrm{a}} \pm 0.01^{\mathrm{c}}$ & $315.88^{\mathrm{a}} \pm 00.2^{\mathrm{c}}$ & $405.23^{\mathrm{a}} \pm 0.02^{\mathrm{c}}$ \\
\hline
\end{tabular}

$\mathrm{a}=$ mean of triplicate samples, $\mathrm{c}=$ standard deviation triplicate samples

\section{DISCUSSION}

Iron load was generally in appreciable level in the dishes, the foods are rich iron contents. Kosai (010) contained the least iron content with value of $4.35 \pm 0.07 \mathrm{mg} / 100 \mathrm{~g}$. Tuwon alkama da miyan kuka (005), Tuwon shinkafa da miyan wake (001) and Tuwon masara da miyan bushashen kubewa (007) have comparable as well as highest iron content. High iron content of these dishes can be as result of their meat content, which is said to be good source of iron as reported [11].

These iron contents in the foods could meet the standard values expected as the required dietary intake in conformity with WHO and FAO standard, thus, able to prevent many iron deficiency like anemia and aforementioned in the review, women of childbearing age, pregnant women and teenage girls are at greatest risk of developing iron deficiency anemia because they have the greatest need for iron. These set of people would find fair remedy when these dishes of high iron content are considered as their meal choice.

Magnesium contents of dishes ranged from $131.30 \pm 0.09$ to $332.40 \pm 0.08 \mathrm{mg} / 100 \mathrm{~g}$. Tuwon alkama da miyan wake (001) being the highest in value of magnesium content. .Kunun gyada (008) and Furan da nono (011) also have closely high value of magnesium. Thus, the appreciable content of the magnesium in these foods will no doubt depict their desirable role in preventing and managing health disorders such as hypertension, cardiovascular diseases and diabetes as a great health concern which affect the mid-aged group.

Phosphorus levels range from $30.75 \pm 0.01$ to $405.23 \pm 0.05 \mathrm{mg} / 100 \mathrm{~g}$. Fura da nono (011) has the highest value. Other foods content of phosphorus are not too bad. However, for them to really have effective phosphorus impact, repeated meals could be a way out. This approach is more particularly suitable in the cases of Tuwon alkama da miyan kuka (005), Masa da miyan ganye (006) and Kunun gyada (008), which have moderate content of phosphorus. These foods with substantial potassium content can be well exploited in the remedy of weak bones formation that usually characterizes the old age.

\section{CONCLUSION}

Comparison of mineral contents with recommended dietary allowance (RDA) and reviews, it is possible to affirm that the dishes contain adequate nutrition for human consumption and can play great roles in the prevention of these elements' deficiencies. It is important to mention that minerals in these dishes are paramount in maintaining a good healthy living, judging by the optimum level of iron, magnesium and phosphorus in the foods. This study has shown the foods such as Tuwon shinkafa da miyan wake (001) and furan da nono (011) to be very valuable due to their rich content in the studied elements. 


\section{REFERENCES}

[1] H. C. Brittin (2010).The food and culture around the world Hand book (Prentice Hall.2010) ISBN-13: 978-0-13-507481-7, ISBN: 0-13-507481-9

[2] UNICEF.Vitamins and minerals Deficiency.A global damage assessment report. : Micronutrient Initiative M.I, New York.2005

[3] Food and Agricultural Organization, The state of food insecurity in the world, FAO, Rome, 2005

[4] Centre for Disease Control and Prevention. Recommendations to prevent and control iron deficiency in the United States, New York,.CDC MMWR New York ,1998, Recomm Rep;47:1-29

[5] R. J.Stoltzfus, Iron-deficiency anaemia: re-examininig the nature and magnititude of the public health problem. Summary: Implication for research and programs. Journal of Nutrition, 131,2001, S697-700

[6] B. M. Altura, ,Basic biochemistry and physiology of Magnesium, A brief review. Magnesium and trace Element, 1991,10:167-171. 2

[7] Ryan M.F., The role of magnesium in clinical biochemistry: an overview. Ann Clin Biochem.1991, 28:19-26

[8] C. Feillet-Coudray, C. Coudray, J. C. Tressol, D. Pepin, A. Mazur, S. A. Abrams, Exchangeable magnesium pool masses in healthy women: effects of magnesium supplementation. America Journal Clinical Nutrition, 2002,75:72-8.

[9] E. B. Lexikon, Dritter Band, Spektrum Akademischer Verlag GmbH, Heidelberg/Berlin 2002, S.116 Phosphate, S. 118 Phosphorus

[10] Dietary Guidelines for Americans: Us dept. of Health and Human Services and US dept. of Agriculture, Rock Ville MD, 2005

[11] G.Löffler, P. E. Petrides, Biochemie und Pathobiochemie. 7. völlig neu bearbeitete Auflage. Springer Verlag, Heidelberg, 2003 S. 702 